\title{
Effecting Community Efforts in Drug Abuse Control: A Study of Delta State Nigeria
}

\section{Ogbebor Godwin Gideon}

\author{
Guidance and Counselling Department \\ Delta State University, \\ Abraka - Delta State, Nigeria. \\ E-mail:ggogbebor@yahoo.com \\ Phone: +2347038317959
}

Doi:10.5901/ajis/2013.2n1p429

\begin{abstract}
The study investigated the effectiveness of some efforts that are made to control hard drug abuse and excess use of alcohol in Delta State Communities in Nigeria. The control efforts investigated were those of psychotherapists, community rules against drug and alcohol usage and efforts related to enforcement of these rules. Also investigated were efforts in the use of extra-curricular activities to control drugs use and efforts to check availability of the illegal drugs. The intention was to find out how much efforts are in place against drug usage and whether illegal drug and excess alcohol usage are effectively controlled in these communities. The purpose was for the research to have basis for making suggestions and recommendations for effective control where necessary. It was a descriptive study that used a survey design guided by six research questions. Data was collected through questionnaire and the chi-square method of data analysis was adopted. The result indicated that the various control measures were available in the three communities although their effectiveness was not significant. The researcher recommended that awareness education should be introduced while law enforcement agencies need to become more effective in their duties to control against illegal hard drug usage and use of excess alcohol.
\end{abstract}

Key Words: Drug Abuse-Control-Community Efforts-Effectiveness

\section{Introduction}

\section{I.I Study Background}

The study investigated community efforts made to control drug and alcohol abuse in Delta State Nigeria. The study was intended to find out relative effectiveness of some identified ways of control in practice in different communities in the State. The efforts investigated include counselling, psychotherapy, school health talk, community rules and sanctions, parental control, religious efforts, peer group and family efforts, sports and recreation efforts.

In Nigeria, Africa community life is practised. Here members of a particular community come together to confront a problem situation whenever it arises. Every members of the community is bound to get involved in such efforts to solve an emerging problem, and sanctions are invoked against any community member that defaults. Since the I $^{\text {th }}$ Century when Nigeria witnessed British colonisation and incursion of Western civilization, drug abuse got introduced in the various communities. Before now, the use of drugs was never a way of life. However, since the advent of this abnormal practice, the 
effects of drugs have been very devastating. There have been various cases of psychological problems, drug related illnesses, and even cases of death as a result of drug use.

Different efforts have been introduced in order to find solutions to these drug problems, yet the efforts cannot be said to be effective. Many young people are found roaming the urban and rural streets aimlessly while some even go naked. Efforts to control the situation from different levels of governance are scarce and ineffective. Hospitals, schools, and some government establishments practise western civilisation and orthodox method of control, while some communities attempt traditional methods. It has, therefore, become necessary to research on these different efforts so as to determine their relative effectiveness for the benefit of the health of people in these communities.

\section{I.2 Literature Review}

The issue of drug abuse involves knowing the meaning, its effects, control and ways drugs are abused. It also involves knowing signs and symptoms of drug effect and why people abuse drugs.

Donaldson, Sussman and Tobler (2000) explained that if your drug use is causing problem in your life, such as at work, school, home, in your relationship, you likely have a drug abuse or drug addiction. They explained the difference between drug abuse and drug addiction. According to them, the difference is not that great but it is important to understand when a person goes from abusing drugs to being addicted to drugs. Drug abuse is when a person uses a drug for something other than a medically prescribed purpose; and it is when a person takes a drug to get high or feel better. When a person takes drugs, more than the prescribed amount or for recreation, have a mood change; it is the taking of drugs that are addictive and harmful to a person's health (Donalson, Sussman and Mackinnon et al., 1996).

They added that when a person goes into addiction, their choice to take drugs is either severely limited or taken away entirely. The person has no choice but must take the drug. It is when the drugs take over, when a person's life is all about getting the drug and taking the drug, when nothing but the drug matters, that is addiction (Dakes, Ullman and Stain, 1996; Newcomb and Earlyman, 1996; and Potraitis, Fray and Mill, 1995).

Australian Queensland Health (1996) explained some effects of drug abuse and addiction. This health organisation states that repeated use of drugs can alter the way the brain functions, causing the feelings of pleasure, so the brain remembers this and wants some more. It causes the rate of eating and drinking, so that the brain is unable to think clearly, exercise good judgement and control behaviour and feel normal without drugs. There is craving to use more, and the drug becomes more important than anything else; and the individual rationalises its use.

The works of Deboral et al. (200I), Botvin (1990) and Jenks and Raymond (I990) show some of the effects of drugs on those who abuse them, and those that are addicted. Sedative hypnotic drugs result in impaired judgement, incoordination and unsteady gait. These drugs are central nervous system depressants and have considerable potentials for psychological problems. The use of amphetamines can result in violent behaviour, agitation and exhilaration, increased energy and alleviation of fatigue; that the use of cocaine cancels hunger while giving the feeling of overestimation of ability, making poor judgements, agitation and rapid speed. Lawson (1993), Miller, Beth and Mark (I99I) and Reid, Douglas, Dele and Andy (1990) identified some drugs and their effects. These include hallucinogens and phencyclidine. These result in perceptual changes, hallucination, dilated pupil, blurred vision, tremors, poor coordination, euphoria, agitation, anxiety, grandiosity and disturbed judgement. As for marijuana and tobacco, the National Cancer Institute states that they cause psychological problems, result in euphoria and intensifies disorientation, and that tobacco results in more than 300,000 deaths per year in America. 
It is the opinion of Shimp and Frank (1988), Stoller and Rachel (I994), Thomas (1979) and Vogt (1992) that those involved in drug problems should see the therapist and also take self-direction, and that they should get people they can lean on for encouragement, comfort and guideline. Apart from what these persons can do, the community has some roles to play in drug control.

Support can come from family members, close friends, therapists and counsellors, other recovering addicts and people from your faith and communities (Wilcox, David and Steffie, 1994; Yee and Gayle, 1984; Ascione and Leslie, 1988; Bandy and Patricia, I983). These people suggest that the community can lay down rules and state consequences, monitor youths involved in drugs and encourage other interests and social activities. They suggest also that the community can talk to the young ones about underlying issues, and let the young ones hear from different authorities, figures and so on. Other efforts may include use of sports coaches, family doctors, therapists or drug counsellors.

But what are the ways drugs are abused in any community? The works of Coons, Jon and Sharon (1988), Des, Don Herman and David (1985), Finlayson (1984) and those of German and Lynda (1989) state that those who use these drugs feel good and they stop them from feeling bad, and that drug users do not know when they become addicted. Also, they use the drugs in company of friends, when they feel bad and uneasy. They are used to fulfil a valuable need.

\section{Signs and Symptoms of Drug Abuse}

The works of Glantze (1985), Gomberg (I990) and Gottheil et al. (1985) reveal certain signs and symptoms seen among those who abuse drugs. These include taking risks, falling into legal troubles and having problems in relationship. The lives of such users revolve around drug use, they abandon activities they used to enjoy and use drugs even when they know it is hurting them. Such drug users have bloodshot eyes, their pupils appear larger or smaller than usual, and they deteriorate in physical appearance and personal grooming habits. Unusual smells on breath, body or clothing may be noticed. They may have tremors, slurred speech or impaired co-ordination. They stated also that such drug users may have sudden mood swings, irritability, or energy outburst, unusual hyperactivity, or angry outburst, unusual hyperactivity, agitation, or giddiness. They may also lack motivation, and appear fearful or paranoid, with no reason.

\section{Help for Drug Abuse}

With the right treatment and support psychologists counteract the disruptive effects of drugs in order to regain control of the users' life. Guttman (1978) said that support can come from family members, close friends, therapists or counsellors, other recovering addicts, health care providers, and other members of the individual's religious body and people in the community. Huffine, Folkman and Richard (1989) added that attempt should not be made to punish, threaten, bribe or preach. Emotional appeals should be avoided, no cover-up for the drug users or take over their responsibilities. Attempt should not be made to hide or throw out drugs, argue with the people when they are high or take drugs with the drug user (Inciardi, Daune, Brain and Karen, 1978; Kail, 1989).

Therapists and counsellors have tried to investigate reasons why people engage in drugs. The works of Botvin, Baker and Dusenbury et al. (1990), Botvin, Baker and Dusenbury (1995), Schinke, Epstain and Diaz et al. (1995) and Johnson, Malley and Rachman (1995) gave the following reasons: unhappiness, crime, divorce, major illness and death of loved ones. Johnson, Mallay and Rachman said that people take drugs to relieve pain or illness. Kayak and Soo (1992) said that people try drugs out of curiosity, to have good time, or because friends are doing it; or in an attempt to improve athletic performance. Others do so to ease another problem such as stress, anxiety or depression. Lamy (1988) 
states that drug use can be as a result of genetic and inherited factors. If your parents smoke and drink alcohol, chances are that you will do the same. If parents were alcoholic, one is likely to have predisposition to abusing that drug. The tendency for one generation to pass it to another is there. Maddox (1988) said that some people have a personality that is more likely to become dependent on drugs such as when a person is curious, and that people may abuse drugs when they want to feel good or when they are depressed, stressed up, when having anxiety in life, lack of confidence and poor selfesteem. Also peer and social pressure, easy access, race, ethnicity and loneliness may predispose individuals to taking drugs.

\section{Research Problem}

In Nigeria communities, the use of illegal drugs and excessive consumption of alcohol has become rampant. It is common to see young men openly smoking marijuana. Other hard drugs are taken secretly by those who can afford them. The psychological effects of these drugs are noticeable among these youths both male and female. It is common to see these persons roaming city and rural streets as lunatics. Middle age adults and the aged are commonly seen lose their poisity as a result of excess alcohol.

The problem of this study, therefore, was to investigate how much control measures are in place in the communities to check hard drug abuse and excessive consumption of alcohol. The researcher wanted to see the types of control available and how available and effective these control measures are.

\section{I Research Questions}

The following research questions were formulated to guide the study.

(i) Are there psychotherapists, psychologists and counsellors in the communities that attend to drug users?

(ii) Are there community rules put in place against use of illegal drugs in your community?

(iii) Is there legal enforcement of the rules against illegal drug use in the community?

(iv) Are there control measures against excess alcohol usage in the communities?

(v) Are there extracurricular activities such as sports, recreation and seminar aimed at reducing illegal hard drug usage in the communities?

(vi) Are there measures put in place to check availability of hard drugs in the communities?

\subsection{Purpose of Study}

The research intended to ascertain how much efforts the Nigeria community makes to reduce illegal drug usage, how much those already in drug usage are helped out of it and how much effort is made to prevent others engaging in drug. The purpose was to know how much effort is made in the communities to control drug and alcohol usage. This knowledge will indicate whether drug control is adequate and whether additional efforts are needed to make drug control more effective.

The situation observed by the researcher is that illegal drug usage and excessive indulgence in alcohol have become of concern. If the issue is left uninvestigated and recommendations not made for effective control, the situation may grow worse. The knowledge of how much control is in place and its effectiveness will help community counsellors to plan and contribute in making drug control more effective. 


\subsection{Research Method}

\subsection{Participants}

The participants in this study were counsellors in secondary and primary schools; teachers, civil servants, literate community leaders and health workers who were used for the study. The convenience sampling method was adopted. This sampling method was adopted to ensure that persons with some knowledge in the subject areas of the research were used as participants. They were instructed on what the research was about. A total of 348 people were used as participants; and a copy of the research questionnaire was issued to each of them to respond to. These participants were sampled from each of the three senatorial districts of Delta State, each one taken as a community entity.

\subsection{Research Instrument}

A questionnaire of I5 items was used to collect information that was analysed. This was drawn up by the researcher to investigate the existence of drug control measures, the spread of these measures and their effectiveness in the three communities. The information supplied was summarised for each of the drug control measures before analysis was made.

\subsection{Procedure}

The research was a descriptive study that used a survey design. The responses returned for each of the control measures were summarised and fitted into each of the research questions. It was these that were analysed that enabled the researcher to answer the research questions earlier formulated to guide the study. It was this analysis that enabled the researcher to arrive at conclusion whether the control measures were available, if they were well spread, adequate and effective.

\section{Results}

The research investigated efforts put in place in the Delta State communities against drug usage. Six research questions were formulated to investigate this. The result showed that there were measures in place in the three communities that make up Delta State of Nigeria; Delta North, Delta Central and Delta South. However, the respondents indicated that the measures put in place against the use of drugs were not significant.

Research question (i) wanted to know if there were psychotherapists, psychologists and counsellors in each of the 3 communities. The (yes) response for the 3 communities was I5I, while the (no) response was I88. There were 9 invalidated responses. The chi-square analysis showed that the availability of these specialists was not significant as measures against use of drugs. The chi-square analysis showed that $x^{2}$ calculated of 2.23I was less than the $x^{2}$ critical of 9.49 at the 0.05 level of significance.

Research question (ii) wanted to investigate if there were rules put in place against use of illegal drugs in the 3 communities being studied. The (yes) response for the 3 communities was I3I while the (no) response was 202 and invalidated responses was I5. The $x^{2}$ calculated of 2.790 was less than the $\mathrm{x}^{2}$ critical of 9.49 at the 0.05 level of significance. This indicated that although there were rules put in place against use of illegal drug usage, these rules were not significant.

Research question (iii) investigated if there were legal enforcement of the rules against illegal use of drugs in the communities. The (yes) response was III while the (no) response was 2I5 with 22 
invalidated responses. The $\mathrm{x}^{2}$ calculated of 2.178 was less than the $\mathrm{x}^{2}$ critical of 9.49 at the 0.05 level of significance. This indicated that although there was legal enforcement of the rules against illegal use of drugs, the enforcement of these rules was not significant.

Research question (iv) investigated if there were control measures against excess usage of alcohol in the communities. The (yes) response was I40 and the (no) response was I99 with 9 responses invalidated. The $x^{2}$ calculated of 2.885 was less than the $x^{2}$ critical of 9.49 at the 0.05 level of significance. This indicated that there were control measures against excess usage of alcohol in the communities, but these control measures were not significant.

Research question ( $v$ ) investigated if there were extracurricular activities such as sports, recreation and seminars put in place aimed at reducing illegal hard drug usage in the communities. The (yes) response was I48 and the (no) response was I84 with I6 invalidated responses. The $\mathrm{x}^{2}$ calculated was 6.906 and was less than the $x^{2}$ critical of 9.49 at the 0.05 level of significance. This result showed that these measures are available in the communities although the response shows that the measures were not significant.

Research question (vi) investigated if there were measures put in place to check availability of hard drugs in the communities. The (yes) response was 133 and the (no) response was 209 with 6 responses invalidated. The $x^{2}$ calculated of 0.025 was less than the $x^{2}$ critical of 9.49 at the 0.05 level of significance. This indicated that although there are measures put in place to check availability of hard drugs in the communities, those measures were not significant.

\section{Discussion}

The study set out to investigate efforts put in place to control drug abuse in the communities in Delta State, Nigeria. The study covered the three communities of Delta North, Delta Central, and Delta South. The intention was to evaluate the effectiveness of the efforts in the 3 communities. The evaluation was to be based on the instrument as suggested by Shimp and Frank (1988), Stoller and Rachel (1994), Thomas (1979) and Vogt (1992). They suggested support by therapists, psychologists and counsellors as efforts against drug abuse. Other efforts include laying down rules and consequences against drug use in the communities as suggested by Wilcox, David and Steffie (1994), Yee and Gayle (1984), Ascione and Leslie (1988) and Bandy and Patricia (1983). They also suggested use of recreation and sporting activities; seminars and talks to the young ones about danger of drug abuse and use of family doctors, therapists and counsellors.

A survey of the use of these efforts against drug usage was made in the 3 communities. This was done through administration of questionnaire (Appendix I). The finding was that these efforts are available in all the communities in Delta State, Nigeria. However, the respondents showed that the efforts were not significant. This was interpreted to mean that although the measure to control drug abuse are there in the communities, they were not effective efforts to control illegal drug usage and excess use of alcohol.

This situation can be assumed to be the reason for the situation the researcher had observed: that the adverse effect of drug abuse is noticeable everywhere and on the streets of Delta State. Even a casual observation by any passer-by will reveal young men and women roaming aimlessly along the streets and some of them taking these drugs openly without any challenge from law enforcement agencies. Adults of various age grades are seen staggering on the streets obviously as a result of excess consumption of alcohol.

The results of this research showed that even though there are some measures and efforts to control illegal drug usage and excess alcohol consumption, these efforts are not enough and so they are not effective. This in turn may be responsible for the observation the researcher made that necessitated 
this investigation. This resultant consequence of insufficient efforts to control illegal usage of drugs agrees with those of Deboral et al. (200I), Botvin (1990) and Jenks and Raymond (1990). They observed that if efforts are not in place to control illegal usage of drugs and excess use of alcohol, users can become addicted and these result in impaired judgement, incoordination and unsteady gait. That the drugs cause psychological problems such as violent behaviour and agitation, euphoria, anxiety, grandiosity and distorted judgement. The works of Botvin (1990) relate to what the situation can be when there are insufficient control measures to check drug abuse. Botvin states that the consequences include hallucination, euphoria, intensified disorientation and even death. This was what the researcher observed that necessitated this study.

\section{Implication}

The results of this research indicated that there were some efforts put in place in the various communities in Delta State, Nigeria to reduce illegal drug usage and excess consumption of alcohol; although these efforts were observed not to be sufficient to be effective. This result emphasises the need to intensify these efforts so that they can become more effective. Counsellors are not commonly found in the various communities except in schools and university campuses. The communities are not well informed of the adverse effects of illegal use of drugs. Because of the poor living standards, people do not engage in leisure hour and recreational activities and sports. People only recreate sitting around and consuming alcohol and going to the dark corners to take drugs. The law enforcement agencies do not show seriousness in their duties, so they are not effective in the drug control efforts. These could be the reasons why drug control efforts have been observed not to be effective. In the face of these situations, the following implications have arisen from this study.

(i) There is the need to include drug issue in health education courses in the secondary schools and in the universities.

(ii) Guidance counsellors should be encouraged by the governments at the state levels to establish offices in the communities where counsellor can give counselling services to the citizens including drug users and alcohol consumers.

(iii) Health talks and seminars need to be organised at the community level so that people will become well informed about the adverse effects of illegal drug usage and excess consumption of alcohol.

(iv) Another implication of the findings of this study is how to ensure that law enforcement agencies become more effective. More studies on how to make this possible should be carried out and the result of such studies implemented.

\section{Recommendations}

Informed by the results obtained from the research, it is recommended that community newspapers and information bulletins pay more attention to drug and alcohol issues. Electronic media houses need to organise debates on drug and alcohol related matters. This will help to promote more information relating to dangers of illegal drug usage. Law enforcement personnel to mix up with the people in the various communities for them to detect how drugs enter the communities and how these drugs are made available to people who use them. This will make drug control efforts to become more effective. If these recommendations are implemented, a lot of improvement will be observed in the communities in drug control efforts. 


\section{References}

Ascione, F.J. and Leslie, A.S. (1988). Helping Patients to reduce Medication Misuse and error. Generations, 4(I2): 52-55.

Australia Queenland Health (1996). Alcohol and other drug use and people from a non-English speaking background. Policy discussion paper (Queenland Health, alcohol, drug and tobacco services).

Bandy, P. and Patricia, A.P. (1983). Recent literature on drug abuse prevention and mass media: Focusing on Youth, patient, women and the elderly. Drug Abuse Prevention and Mass Media, 3(I3): 255 - 267.

Botvin, G.I. (1990). Substance abuse prevention: Theory, practice and effectiveness. In Drug and Crime ed. by Tommy and J.Q. Wilson. Chicago, III: University of Chicago.

Botvin, G.J., Baker, E. and Diaz, J. (I995). Long term follow up results of a randomized drug abuse prevention trial. Journal of American Medical Association, 273, I 106 - II 12.

Botvin, G.J., Baker, E. and Dusenburg, L. et al. (I990). Preventing adolescent drug abuse through a multimodal cognitive - behavioural approach: Result of a 3 year study. Journal of Consulting and Clinical Psychology, 58(4): $437-446$.

Botvin, G.J., Shinke, S.P., Epstain, J.A. and Diaz, T. (I995). Effectiveness of culturally focused and generic skills training approaches to alcohol and drug abuse prevention among minority adolescents; Two-year follow-up result. Psychology of Addictive Behaviours, 9(3): I83 - I94.

Coons, Jon and Sharon, S.L. (I988). Drinking in retirement communities. Generations, 4(I2): 58-62.

Dakes, R., Ullman, J. and Stain, J. (I996). Three year follow up of drug abuse resistance education (DARE). Evaluation Review, 20, 49-66.

Deboral, S. et al. (200I). Delivering drug services to black and minority ethnic communities (Home office, United Kingdom of Great Britain and Northern Ireland).

Des, J., Don, C., Herman, J. and David, T.C. (1985). Old age and addiction: A study of elderly patients in Methadone Maintenance treatment in The Combined Problems of Drug Addiction and Aginig. Springfield, EL; Charles C. Thomas.

Donalson, S.I., Street, G., Sussman, S. and Tobler, N. (2000). Using meta-analyses to improve the design of interventions. In S. Sussman (ed.) Handbook of Program-development for health behaviour research. Newbury Park, C.A. Sage, pp. 449-466.

Donalson, S.I., Sussman, S. and Mackinnon, D.P. et al. (1996). Drug abuse prevention programme: Do we know what content works? American Behavioural Scientists, 39, $869-883$.

Finlayson, R.E. (1984). Prescription drug abuse in old persons. Alcohol and Drug Abuse in Old Age. Washington, D.C. American Psychiatric Press, Inc.

German, P.S. and Lynda, C.B. (I989). Clinicians, the Elderly and Drug. The Journal of Drug Issues. I9:22I 243.

Glantze, M.D. (1985). The Detection, Identification and differentiation of elderly drug misuse and abuse in a Research Survey in the combined problems of alcoholism, drug addiction and aging. Springfield, II: Charles C. Thomas.

Gomberg, E.I. (1990). Drugs, alcohol and aging. In Research Advances in Alcohol and Drug Problems. ed. by L. Koziowaki, H., Annis, H. Cappell, F. Gbser, M. Goodstadt, Y. Israel, H. Kalat, E. Sellers, E. Vingilis. New York: Plenum Press.

Gottheil, E., Keith, A.D., Thomas, E.S. and Howard, M.W. (I985). The Combined Problems of Alcoholism and Aging. Springfield II: Charles C. Thomas.

Guttheil, E.K.A., Druly, T.E.S. and Howard, M.W. (1985). The combined problems of alcoholism, drug addiction and aging. Springfield, H: Charles C. Thomas.

Guttman, D. (1978). Pattern of Legal Drug use by Older American. Addictive Disease: an International Journal (3): $337-356$.

Huffine, C.S., Folkman, R.S. and Richard, S.L. (1989). Psychoactive Drugs, Alcohol, and stress and coping processes in Older Adults. American Journal of Alcohol Abuse (I5): IOI - II3.

Inciardi, J.A., Daune, C.M., Brain, R. and Karen, S.W. (1978). Acute Drug Reactions among the Aged: A Research Note. Addictive Disease: An International Journal, 3(3): 383 - 388. 
Jenks, M.J. and Raymond, R.R. (1990). A profile of alcohol and prescription drug abuse in a high-risk community-based elderly population (DICP). The Annels of Pharmacotherapy (24): 97I-975.

Johnson, I.D., Maley, P.M., Rachman, J.G. (1995). National Survey results on drug use from the monitoring the future study, 1975 -1994, Vol. I. Secondary School Students. Washington D.C. U.S.A. Department of Health and Human Services.

Kail, B.L. (1989). Family, Friends and Neighbours: The Role of Primary Groups in Preventing Misuse of Drugs. The Journal of Drug, 19:26I - 28I.

Kayak, H.A. and Soo, B. (1992). Coping with chronic illness and disability, in Aging, Health and behaviour (Ed) by M.G. Org. R.P. Abele. PD. Lipman. Newbury Park C.A. SAGE.

Lamy, P.P. (1988). The Aging: Drug use and misuse. In the combined problems of alcoholism, drug addiction and aging. Springfield, II: Charles C. Thomas.

Lawson, A. (1993). Alcoholism and substance abuse in special population (ed) Gary W. Lawson, San Diego, C.A.: United States International University.

Maddox, G.I. (I988). Aging, drinking, and alcohol abuse. Generations, 4(I2): I4-I6.

Miller, N.S., Beth, M.B. and Mark, S.G. (1990). Alcohol and drug dependence among the elderly: Epidemiology, Diagnosis and Treatment. Comprehensive Psychiatry. 2(32): I53 - I65.

National Career Institute (I99I). Strategies to control tobacco use in the United States: A blueprint for public health action in the 1990s. U.S. Department of Health and Human Services, NIH Publication No. 92 3316.

Newcomb, M. and Earlywine, M. (1996). Intrapersonal contributions to drug use: The willing host. American Behavioural Scientist, 39, $823-837$.

Petraits, J., Fray, B.R. and Mill, T.Q. (I995). Reviewing theories of adolescent substance abuse: organizing pieces of the puzzle. Psychological Bulletin, II7, 67-86.

Reid, L., Douglas, D.B., Christensen, A.S. (I990). Medical and psychosocial factors predictive of psychotropic drug use in elderly patients. American Journal of Public Health, II(90):I349-I353.

Shimp, L.A. and Frank, J.A. (I988). Causes of medication misuse and error. Generation, 4(I2): 17-2I.

Stoller, E.P. and Rachel, P. (1994). Affecting the frequency of health enhancing behaviour by the elderly. Public Health Report, 3(I09):377-388.

Thomas, D.L. (1979). Clinical and administrative aspect of drug misuse in nursery homes in Drug and the elderly: Sp issues. P.II.

Vogt., T.M. (1992). Stress and illness: Psychobiological linkage. An Aging, Health and Behaviour (ed) by M.G. Ory, R.P. Abele, P.D. Lipman, Newbury Park. CA: SAGE.

Wilcox, S.M., David, H.H. and Steffie, W. (1994). Inappropriate drug prescribing for the Community dwelling elderly. Journal of the American Medical Association, 4(272): 292 - 317.

Yee, B.W. and Gayle, D.W. (I984). Ethnic minority and health promotion: Developing a culturally competent agenda. Generations Spring, 1994:39-44.

\section{Tables}

\section{Research Question I:}

Table I: Chi-square analysis of whether psychologists, psychotherapists and counsellors that attend to drug users are available in the three Senatorial Districts in Delta State.

Are there psychotherapists, psychologists and counsellors in the communities that attend to drug users?

\begin{tabular}{|c|c|c|c|c|c|c|c|c|c|}
\hline Communities & $\begin{array}{c}\text { Yes } \\
\text { Response }\end{array}$ & $\begin{array}{c}\text { No } \\
\text { Response }\end{array}$ & $\begin{array}{l}\text { Invalidated } \\
\text { Response }\end{array}$ & Total & Df & $\mathrm{X}^{2}$ Calc. & $\mathrm{X}^{2}$ Crit. & $\begin{array}{c}\text { Level of } \\
\text { Sig. }\end{array}$ & Decision \\
\hline Delta North & 52 & 62 & 2 & 116 & \multirow{4}{*}{4} & \multirow{4}{*}{$2.23 \mathrm{I}$} & \multirow{4}{*}{9.49} & \multirow{4}{*}{0.05} & \multirow{4}{*}{$\begin{array}{c}\text { Not } \\
\text { significant }\end{array}$} \\
\hline Delta Central & 49 & 65 & 2 & II6 & & & & & \\
\hline Delta South & 50 & $6 \mathrm{I}$ & 5 & II6 & & & & & \\
\hline Total & I5I & 188 & 9 & 348 & & & & & \\
\hline
\end{tabular}




\section{Research Question II:}

Table II: Chi-square analysis of Research Question II.

Are there community rules put in place against use of illegal drugs in your community?

\begin{tabular}{|c|c|c|c|c|c|c|c|c|c|}
\hline Communities & $\begin{array}{c}\text { Yes } \\
\text { Response }\end{array}$ & $\begin{array}{c}\text { No } \\
\text { Response }\end{array}$ & $\begin{array}{c}\text { Invalidated } \\
\text { Response }\end{array}$ & Total & Df & $\mathrm{X}^{2}$ Calc & $\mathrm{X}^{2}$ Crit. & $\begin{array}{l}\text { Level of } \\
\text { Sig. }\end{array}$ & Decision \\
\hline Delta North & 43 & 68 & 5 & II6 & \multirow{4}{*}{4} & \multirow{4}{*}{2.780} & \multirow{4}{*}{9.49} & \multirow{4}{*}{0.05} & \multirow{4}{*}{$\begin{array}{c}\text { Not } \\
\text { significant }\end{array}$} \\
\hline Delta Central & 47 & 62 & 7 & II6 & & & & & \\
\hline Delta South & $4 \mathrm{I}$ & 72 & 3 & II6 & & & & & \\
\hline Total & I3I & 202 & I5 & 348 & & & & & \\
\hline
\end{tabular}

\section{Research Question III:}

Table III: Chi-square analysis of Research Question III.

Are there legal enforcement of the rules against illegal drug use in the community?

\begin{tabular}{|c|c|c|c|c|c|c|c|c|c|}
\hline Communities & $\begin{array}{c}\text { Yes } \\
\text { Response }\end{array}$ & $\begin{array}{c}\text { No } \\
\text { Response }\end{array}$ & $\begin{array}{c}\text { Invalidated } \\
\text { Response }\end{array}$ & Total & Df & $\mathrm{X}^{2}$ Calc. & $\mathrm{X}^{2}$ Crit. & $\begin{array}{c}\text { Level of } \\
\text { Sig. }\end{array}$ & Decision \\
\hline 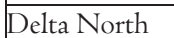 & 38 & 73 & 5 & I16 & \multirow{4}{*}{4} & \multirow{4}{*}{2.178} & \multirow{4}{*}{9.49} & \multirow{4}{*}{0.05} & \multirow{4}{*}{$\begin{array}{c}\text { Not } \\
\text { significant }\end{array}$} \\
\hline Delta Central & 35 & 74 & 7 & II6 & & & & & \\
\hline \begin{tabular}{|l|l} 
Delta South \\
\end{tabular} & 38 & 68 & I0 & II6 & & & & & \\
\hline Total & III & 215 & 22 & 348 & & & & & \\
\hline
\end{tabular}

Research Question IV:

Table IV: Chi-square analysis of Research Question IV

Are there control measures against excess alcohol usage in the communities?

\begin{tabular}{|c|c|c|c|c|c|c|c|c|c|}
\hline Communities & $\begin{array}{c}\text { Yes } \\
\text { Response }\end{array}$ & $\begin{array}{c}\text { No } \\
\text { Response }\end{array}$ & $\begin{array}{c}\text { Invalidated } \\
\text { Response }\end{array}$ & Total & Df & $\mathrm{X}^{2}$ Calc. & $\mathrm{X}^{2}$ Crit. & $\begin{array}{c}\text { Level of } \\
\text { Sig. }\end{array}$ & Decision \\
\hline Delta North & 46 & 69 & I & 116 & \multirow{4}{*}{4} & \multirow{4}{*}{2.885} & \multirow{4}{*}{9.49} & \multirow{4}{*}{0.05} & \multirow{4}{*}{$\begin{array}{c}\text { Not } \\
\text { significant }\end{array}$} \\
\hline Delta Central & 48 & 65 & 3 & 116 & & & & & \\
\hline Delta South & 46 & 65 & 5 & I16 & & & & & \\
\hline Total & 140 & 199 & 9 & 348 & & & & & \\
\hline
\end{tabular}

\section{Research Question V:}

Table V: Chi-square analysis of Research Question V.

Are there extracurricular activities such as sports, recreation and seminar aimed at reducing illegal hard drug usage in the communities?

\begin{tabular}{|c|c|c|c|c|c|c|c|c|c|}
\hline Communities & $\begin{array}{c}\text { Yes } \\
\text { Response }\end{array}$ & $\begin{array}{c}\text { No } \\
\text { Response }\end{array}$ & $\begin{array}{c}\text { Invalidated } \\
\text { Response }\end{array}$ & Total & Df & $\mathrm{X}^{2}$ Calc. & $\mathrm{X}^{2}$ Crit. & $\begin{array}{c}\text { Level of } \\
\text { Sig. }\end{array}$ & Decision \\
\hline Delta North & 52 & 58 & 6 & 116 & \multirow{4}{*}{4} & \multirow{4}{*}{6.906} & \multirow{4}{*}{9.49} & \multirow{4}{*}{0.05} & \multirow{4}{*}{$\begin{array}{c}\text { Not } \\
\text { significant }\end{array}$} \\
\hline Delta Central & 46 & $6 \mathrm{I}$ & 9 & II6 & & & & & \\
\hline Delta South & 50 & 65 & $\mathrm{I}$ & II6 & & & & & \\
\hline Total & I48 & I85 & I6 & 348 & & & & & \\
\hline
\end{tabular}




\section{Research Question VI:}

Table VI: Chi-square analysis of Research Question VI.

Are there measures put in place to check availability of hard drugs in the communities?

\begin{tabular}{|c|c|c|c|c|c|c|c|c|c|}
\hline Communities & $\begin{array}{c}\text { Yes } \\
\text { Response }\end{array}$ & $\begin{array}{c}\text { No } \\
\text { Response }\end{array}$ & $\begin{array}{c}\text { Invalidated } \\
\text { Response }\end{array}$ & Total & Df & $\mathrm{X}^{2}$ Calc. & $\mathrm{X}^{2}$ Crit & $\begin{array}{c}\text { Level of } \\
\text { Sig. }\end{array}$ & Decision \\
\hline Delta North & 44 & 70 & 2 & I16 & \multirow{4}{*}{4} & \multirow{4}{*}{0.025} & \multirow{4}{*}{9.49} & \multirow{4}{*}{0.05} & \multirow{4}{*}{$\begin{array}{c}\text { Not } \\
\text { significant }\end{array}$} \\
\hline Delta Central & 44 & 70 & 2 & II6 & & & & & \\
\hline Delta South & 45 & 69 & 2 & I16 & & & & & \\
\hline Total & I33 & 209 & 6 & 348 & & & & & \\
\hline
\end{tabular}

\section{Appendix I}

\section{Questionnaire}

\section{Drug Control Efforts in the Community}

Instruction: Tick the box ( V) where appropriate

I. Indicate type of Community: Rural

2. Do you notice drug abuse among people in your community? Yes [ ] No [

3. Do you notice drug related ailment in your community? Yes [ ] No [

4. State if it is: Hard drug [ ] or alcohol [ ] both [ ]

5. Are there therapists, counsellors or psychologists in your community? Yes [ ] No [

6. Are there association of persons recovering from drugs in your community? Yes [ ] No [

7. Do family members, or close friends of drug abusers help against use of drugs? Yes [ ] No [ ]

8. Do you notice religious bodies that help those involved in drug abuse? Yes [ ] No [

9. Are there community rules and sanction against hard drug use in your community? Yes [ ] No [

I0. Are there community rules and sanctions against excess alcohol usage in your community? Yes [ ] No

II. Are there bodies set up by the community to check illegal drug usage in your community? Yes [ ] No [

12. Are there sporting activities set up by the community to redirect youths' interest from drug usage? Yes [ ] No [

13. Are there Seminars, talks, lectures organised where issues related to drug abuse are discussed? Yes [ ] No [ ]

I4. What are types of illegal drugs commonly accessible to the drug users?

I5. Marijuana [ ] LSD [ ] Cocaine [ ] heroine [ ]

I6. Are the control measures against drug use reducing their usage? Yes [ ] No [ ] 


\section{HYPOTHESIS A \\ CROSSTABS ANALYSIS}

\section{CROSSTABS}

/TABLES-COMMUNTTY BY RESPONSES

/FORMAT=AVALUR TABLES

/STATISTICS=CHISO

/CELLS-COUNT EXPBCTED SRESTD

ICOUNT ROCND CELL

/RETHOD-Exact TIMER (5).

\section{Crosstabs}

\section{[Dataset 0]}

\begin{tabular}{|c|c|c|c|c|c|c|}
\hline \multicolumn{7}{|c|}{ Case Processing Summary } \\
\hline & \multicolumn{6}{|c|}{ Cases } \\
\hline & \multicolumn{2}{|c|}{ Valid } & \multicolumn{2}{|c|}{ Missing } & \multicolumn{2}{|c|}{ Total } \\
\hline & $\mathrm{N}$ & Percent & $\mathrm{N}$ & Percent: & $\mathrm{N}$ & Percent \\
\hline $\begin{array}{l}\text { DELTA NORTH }=1 ; \\
\text { DELTA CENTRAL }=2 \text {; } \\
\text { DELTA SOUTH }=3 \cdot \text { YES } \\
=1 \text { NO }=2 \text { =INVALV }=3\end{array}$ & 348 & $100.0 \%$ & 0 & $.0 \%$ & 348 & $100.0 \%$ \\
\hline
\end{tabular}

DELTA NORTH $=1$; DELTA CENTRAL $\approx 2$; DELTA SOUTH $=3 \cdot$ YES $=1 ;$ NO $=2 ;$ INVALID $=$ : Crosstabulation

\begin{tabular}{|c|c|c|c|c|c|c|}
\hline & & & \multicolumn{3}{|c|}{ YES $=1$ NO $=2:$ INVALID $=3$} & \multirow[b]{2}{*}{ Total } \\
\hline & & & 1 & 2 & 3 & \\
\hline \multirow{9}{*}{$\begin{array}{l}\text { DELTA NORTH }=1 ; \\
\text { DELTA CENTRAL }=2 \text {; } \\
\text { DELTA SOUTH }=3\end{array}$} & 1 & Count & 52 & 62 & 2 & 116 \\
\hline & & Expected Count & 50.3 & 62.7 & 3.0 & 116.0 \\
\hline & & Std Residual & 2 & 0 & -6 & \\
\hline & 2 & Count & 49 & 65 & 2 & 116 \\
\hline & & Expected Count & 50.3 & 62.7 & 30 & 116.0 \\
\hline & & Std Residual & -2 & 3 & -6 & \\
\hline & 3 & Count & 50 & 61 & 5 & 116 \\
\hline & & Expected Count & 50.3 & 62.7 & 3.0 & 196.0 \\
\hline & & Std Residual & 0 & -2 & 12 & \\
\hline \multirow[t]{2}{*}{ Total } & & Count & 151 & 188 & 9 & 348 \\
\hline & & Expected Count & 1510 & 188.0 & 80 & 3480 \\
\hline
\end{tabular}

\begin{tabular}{|c|c|c|c|c|c|c|}
\hline & Value & at & $\begin{array}{l}\text { Asymp. Sig } \\
\text { 2-sioged }\end{array}$ & $\begin{array}{c}\text { Exact Sig (2. } \\
\text { ssided? }\end{array}$ & $\begin{array}{l}\text { Exact Sig (1- } \\
\text { sidinds }\end{array}$ & $\begin{array}{c}\text { Point } \\
\text { Probabitity }\end{array}$ \\
\hline Pearson Chi-Square & 2.231. & 4 & 693 & $\bullet$ & & \\
\hline Lhelihood Ratio & 2065 & 4 & 718 & .741 & & \\
\hline Fishars Exact Test & 1.985 & & & 759 & & \\
\hline $\begin{array}{l}\text { Linear-by Lineat } \\
\text { Association } \\
\text { N af Valad Cases }\end{array}$ & 366: & 1 & 545 & .586 & 293 & .040 \\
\hline
\end{tabular}

\footnotetext{
a. 3 cels (33.3\%) have expected count less than 5 . The mirimum expected count is 3.00 .

b. Cannot be compleded because there is insufficient memory.

c. The standardied statistic is 606 .
} 


\title{
HYPOTHESIS B \\ CROSSTABS ANALYSIS
}

\author{
chosstass \\ ITABLES-CONDUNTTY BY RESPONSES \\ /FORUAT-AVALUE TABLS \\ / \\ ICELLS-COUNT EXPECTED SRESID \\ reount ROUND CELt. \\ fMETHob-Exhet trMER(5).
}

\section{Crosstabs}

\section{[Dataset0|}

\begin{tabular}{|c|c|c|c|c|c|c|}
\hline & \multicolumn{6}{|c|}{ Cases } \\
\hline & & & Miss & & & \\
\hline & $\mathrm{N}$ & Percent & $\mathrm{N}$ & Percent & $\mathrm{N}$ & Percent \\
\hline $\begin{array}{l}\text { DELTA NORTH }=1 \text {; } \\
\text { DELTA CENTRAL }=2 \text {; } \\
\text { DELTA SOUTH }=3 . \text {. YES } \\
\text { s1NO }=2 \text {. }\end{array}$ & 348 & $1000 \%$ & 0 & $0 \%$ & 348 & $100 \mathrm{~cm}$ \\
\hline
\end{tabular}

DELTA NORTH $=1$; $\quad$ DELTA CENTRAL $=2$; CrOsstabulation

\begin{tabular}{|c|c|c|c|c|c|c|}
\hline & & & \multicolumn{3}{|c|}{ VES $=1$, NO $=2$. INVALID $=3$} & \multirow[b]{2}{*}{ Totat. } \\
\hline & & & 1 & 2 & 3 & \\
\hline \multirow{9}{*}{$\begin{array}{l}\text { DELTA NORTH =1: } \\
\text { DELTA CENTRAL }=2 \text {. } \\
\text { DELTA SOUTH }=3\end{array}$} & 1 & Coum & 43 & 68 & 5 & 116 \\
\hline & & Expected Count & 43.7 & 67.3 & 5.0 & $\$ 160$ \\
\hline & & Std. Residual & -1 & \pm & 0 & \\
\hline & 2 & Count & 47 & 62 & 7 & 116 \\
\hline & & Expected Count & 43.7 & 673 & 50 & 116.0 \\
\hline & & Std. Residual & 5 & -6 & 9 & \\
\hline & 3 & Count & 41 & 72 & 3 & 116 \\
\hline & & Expected Court & 43.7 & 67.3 & 5.0 & 116.0 \\
\hline & & Std Residual & -4 & 6 & -9 & \\
\hline \multirow[t]{2}{*}{ Total } & & Count & 131 & 202 & 15 & 348 \\
\hline & & Expected Count & 131.0 & 2020 & 150 & 348.0 \\
\hline
\end{tabular}

Chi-Square Tests

\begin{tabular}{|c|c|c|c|c|c|c|}
\hline & Value & at & Asymp. Sig & $\begin{array}{l}\text { Exact Sig } 12- \\
\text { sisted }\end{array}$ & $\begin{array}{l}\text { Exact Sig (1. } \\
\text { nided) }\end{array}$ & $\begin{array}{l}\text { Point } \\
\text { Probabinty. }\end{array}$ \\
\hline Pearson Chi-Square & 2.7804 & 4 & 595 & 608 & & \\
\hline Likelhood Ratio & 2.827 & 4 & 587 & 602 & & \\
\hline Fisher's Exact Test & 2757 & & & 607 & & \\
\hline $\begin{array}{l}\text { Linear-by Linear } \\
\text { Association }\end{array}$ & $000=$ & 1 & 1.000 & 1.000 & 524 & 047 \\
\hline
\end{tabular}

a. 0 cells $(.0 \%)$ have expected count less than 5 . The minimum expected count is 5.00 .

b. The standardized stativic is,, 000 


\section{HYPOTHESIS C \\ CROSSTABS ANALYSIS}

\section{cacoszass}

/TARTKS-CoveusuTY BY RESPONSS

/FORMAT-AVALUE TABLES

/3TAtratres-Chr9Q

fCELLS-COUNT EXPECrED SAEStI

foount houv CRIL

MeTHOb-Exact TIMER(S).

\section{Crosstabs}

[Dateset 01

Case Processing Summary

\begin{tabular}{|c|c|c|c|c|c|c|}
\hline & \multicolumn{6}{|c|}{ Cases: } \\
\hline & \multicolumn{2}{|c|}{ Vold } & \multicolumn{2}{|c|}{ Miseing } & \multicolumn{2}{|c|}{ Total } \\
\hline & N & Percent & $\mathbf{N}$ & Perrent & $N$ & Percent \\
\hline $\begin{array}{l}\text { DELTA NORTH }=1 \text {; } \\
\text { DELIA CENTIRAL }=2 \text {, } \\
\text { DELTA SOUTH }=3 \cdot \text { VES } \\
\text { "INO } 2 \text {. INWALID }=3\end{array}$ & 348 & $100.0 \%$ & 0 & on & 348 & 100.04 \\
\hline
\end{tabular}

DELTA NORTH $=1$; DELTA CENTRAL $=2$; DELTA SOUTH $=3$ * YES $=1 ;$ NO $=2$; INVALID $=$ :

\begin{tabular}{|c|c|c|c|c|c|c|}
\hline & & & \multicolumn{3}{|c|}{ YES $=1, N O=2$. NVALIO $=3$} & \multirow[b]{2}{*}{ Total } \\
\hline & & & 1 & 2. & 3 & \\
\hline \multirow{9}{*}{$\begin{array}{l}\text { DELTA NORTA =1, } \\
\text { DELTA CENTRAL }=2 \text {; } \\
\text { DELTA SOUTH =3 }\end{array}$} & 1 & Count & 38 & 73 & 5 & 116 \\
\hline & & Expected Count & 370 & 717 & 7.3 & 1160 \\
\hline & & Ssd Residual & 2 & 2 & -9 & \\
\hline & 2 & Count & 35 & 74 & 7 & 116 \\
\hline & & Expected Count & 37.0 & 71.7 & 7.3 & 116.0 \\
\hline & & Std Residual & -3 & $\mathbf{3}$ & -1 & \\
\hline & 3. & Count & 38 & 68 & 10 & 116 \\
\hline & & Expected Count & 37.0 & 71.7 & 7.3 & 118.0 \\
\hline & & Stat Resictual & 2 & .4 & 10 & \\
\hline \multirow[t]{2}{*}{ Total } & & Coart & 111 & 215 & 22 & $34 \mathrm{H}$ \\
\hline & & Expected Count & 1110 & 215.0 & 22.0 & 340.0 \\
\hline
\end{tabular}

Chi-Square Tests

\begin{tabular}{|c|c|c|c|c|c|c|}
\hline & Volue & et & $\begin{array}{l}\text { Aaymp Sig. } \\
\text { C-sided }\end{array}$ & $\begin{array}{l}\text { Exact } \operatorname{Sig}, 12 \\
\text { sided. }\end{array}$ & $\begin{array}{l}\text { Exact Sig (1- } \\
\text { sided }\end{array}$ & $\begin{array}{c}\text { Point } \\
\text { Probateitsy }\end{array}$ \\
\hline Pearson Chi Square & 2.178 & 4 & 703 & 702 & & \\
\hline Likelihood Ratio & 2.176 & 4 & 703 & 708 & & \\
\hline Fisher's Exact Test & 2.133 & & & 713 & & \\
\hline $\begin{array}{l}\text { Linear-by-Linear } \\
\text { Association }\end{array}$ & 339 & $t$ & 560 & 601 & 300 & $\cos \theta$ \\
\hline$N$ of Valid Cases & 348 & & & & & \\
\hline
\end{tabular}

a. 0 cells ( OSw) have expected count less than 5 . The minimum expected court is 7.33 .

b. The standardized statistic is 582 . 


\title{
HYPOTHESIS D \\ CROSSTABS ANALYSIS
}

\author{
crosstaBs \\ ITABLES-CONETUETTY BY RESPCWSES \\ IFORMAT-AVALUE TABLES \\ I ITATTSTTCB-CITBQ \\ ICELLS-COUNT EXPECTED SRESID \\ /COUNT MOURD CELI \\ METHoD-txaCt TtMER $(5)$.
}

\section{Crosstabs}

\{bataseto\}

\begin{tabular}{|c|c|c|c|c|c|c|}
\hline & \multicolumn{6}{|c|}{ Cases } \\
\hline & & & Ms & & & \\
\hline & $\mathrm{N}$ & Percent & $\mathrm{N}$ & Percent & $\mathrm{N}$ & Percent \\
\hline $\begin{array}{l}\text { DELTA NORTH }=1 ; \\
\text { DELTA CENTRAL }=2 \\
\text { DELTA SOUTH }=3 \text {. YES } \\
\text { mINO }=2 \text { INVALD }=3\end{array}$ & 348 & $100.0 \%$ & 0 & $.0 \%$ & 348 & $100.0 \%$ \\
\hline
\end{tabular}

DELTA NORTH $=1$ : DELTA CENTRAL $=2$; DELTA SOUTH $=3 \cdot$ YES $=1 ;$ NO $=2:$ INVALID $=$ : Crosstabulation

\begin{tabular}{|c|c|c|c|c|c|c|}
\hline & & & \multicolumn{3}{|c|}{ YES $=1$ NO $=2$ INVALID $=3$} & \multirow[b]{2}{*}{ Total } \\
\hline & & & 1 & 2. & 3 & \\
\hline \multirow{9}{*}{$\begin{array}{l}\text { DELTA NORTH =1; } \\
\text { DELTA CENTRAL }=2 \text { : } \\
\text { DELTA SOUTH = } 3\end{array}$} & 1 & Count & 46 & 60 & 1 & 116 \\
\hline & & Expected Coumt & 46.7 & 68.3 & 3.0 & 116.0 \\
\hline & & Std Residual & 0 & 3 & -12 & \\
\hline & 2 & Count & 48 & 65 & 3 & 116 \\
\hline & & Expected Count & 46.7 & 68.3 & 30 & 1160 \\
\hline & & Stud Residual & 2 & -2 & 0 & \\
\hline & 3 & Count & 45 & 65 & 5 & 116 \\
\hline & & Expected Coum & 46.7 & 683 & 3.0 & 1160 \\
\hline & & Std Residual & 0 & -2 & 12 & \\
\hline \multirow[t]{2}{*}{ Total } & & Count & 140 & 199 & 9 & 348 \\
\hline & & Expected Count & 1400 & 1900 & 90 & 3480 \\
\hline
\end{tabular}

\begin{tabular}{|c|c|c|c|c|c|c|}
\hline & Votes & ot & Asyomp. Sig & $\begin{array}{c}\text { Exact Sig ing. } \\
\text { sided }\end{array}$ & $\begin{array}{l}\text { Eacisig (1- } \\
\text { soed }\end{array}$ & $\begin{array}{l}\text { Point } \\
\text { Probability }\end{array}$ \\
\hline Pearson Ch-Square & 2885 & 4 & .577 & 592 & & \\
\hline Likeahood Rato & 3.128 & 4 & 537 & 570 & & \\
\hline Fahers Exact Test & 2783 & & & 607 & & \\
\hline $\begin{array}{l}\text { Linear-oy Linear } \\
\text { Astoocison }\end{array}$ & $240 \mathrm{k}$ & 1 & 624 & esea & 334 & 049 \\
\hline
\end{tabular}

a. 3 cels (33.3\%) have expected count less than 5. The minimum expected count is 3.00

b. The standardued statisfic a 490 . 


\title{
HYPOTHESISE \\ CROSSTABS ANALYSIS
}

\author{
cnosstaes \\ ITARERS-CoveristTY BY RESpowses \\ IrORMAT-AVALUE TABLES \\ /sTatistres-CHIBO \\ /CELLS-Count EXPECTED skBsID \\ lcount nouND CELL. \\ Metmod-exact THEsk(5).
}

\section{Crosstabs}

\begin{tabular}{|c|c|c|c|c|c|c|}
\hline & & & $\mathrm{Ca}$ & & & \\
\hline & \multicolumn{2}{|c|}{ Valia } & \multicolumn{2}{|c|}{ Misting } & \multicolumn{2}{|c|}{ Tetal } \\
\hline & $\mathrm{N}$ & Pencent & $\mathrm{N}$ & Percent & $\mathbf{N}$ & Pencent \\
\hline 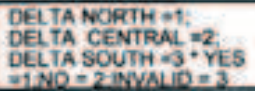 & 308 & $1000 \mathrm{~m}$ & 0 & ow & 348 & $1000 \mathrm{~W}$ \\
\hline
\end{tabular}

\begin{tabular}{|c|c|c|c|c|c|c|}
\hline \multirow[t]{3}{*}{ DELTA NORTH E1: } & \multicolumn{6}{|c|}{$\begin{array}{r}\text { DELTA CENTRAL }=2 ; \\
\text { Crosstabula }\end{array}$} \\
\hline & & & \multicolumn{3}{|c|}{ YES $=1$, NO $=2$, INVALID $=3$} & \multirow[b]{2}{*}{ Ietal } \\
\hline & & & 1 & 2 & 3 & \\
\hline \multirow{9}{*}{$\begin{array}{l}\text { DELTA NOATH }-1 \text {; } \\
\text { DELTA CENTRAL }=2 \text {; } \\
\text { DELTA SOUTH *3 }\end{array}$} & 1 & Count & 52 & se & 6 & 116 \\
\hline & & Expected Coumt & 45.3 & 61.3. & 5.3 & 1160 \\
\hline & & Sad Fiesidual & 4 & -4 & 3 & \\
\hline & 2 & Coum & 46 & B1 & 9 & $\$ 16$ \\
\hline & & Expectied Cosunt & 40.3 & 61.3 & 5.3 & $\$ 160$ \\
\hline & & Std Resibual & -5 & 0 & 16 & \\
\hline & 3 & Count & 50 & 68 & 1 & 316 \\
\hline & & Enpected Count & 49.3 & 61.3 & 5.3 & 116.0 \\
\hline & & Std. Residial & $t$ & 5 & 19 & \\
\hline \multirow[t]{2}{*}{ Total } & & Cant & 148 & 184 & 16 & 348 \\
\hline & & Expected Count & 1480 & 1840 & 160 & 3480 \\
\hline
\end{tabular}

\section{Chi-Square Tests}

\begin{tabular}{|c|c|c|c|c|c|c|}
\hline & Value & at & Asymp sig & $\begin{array}{l}\text { Exact Sig } 12 \\
\text { sided }\end{array}$ & $\begin{array}{c}\text { Exact Sig (1. } \\
\text { sided of }\end{array}$ & $\begin{array}{l}\text { Point } \\
\text { Probabality }\end{array}$ \\
\hline Pearson Chi-Square & 6.906. & 4 & 141 & 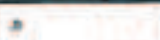 & & \\
\hline Likelihood Rato & 8.266 & 4 & .082 & 091 & & \\
\hline Fisher's Exact Test & 7437 & & & 110 & & \\
\hline $\begin{array}{l}\text { Linear-by-Linear } \\
\text { Association }\end{array}$ & 118 & 1 & 731 & .775 & 367 & 043 \\
\hline $\mathrm{N}$ of Valid Cases & $34 \mathrm{~A}$ & & & & & \\
\hline
\end{tabular}

a. 0 cells $(0 \%)$ have expected coumt less than 5 . The minitrum expected count is 5.33 .

b. Cannet be computed because there is inwuiffient memory.

e. The standardized statistic is -344 . 


\section{HYPOTHESIS F \\ CROSSTABS ANALYSIS}

CaOsatars

ITABLES COMMUNTTY BY RESPONSES

IFORMAT-AVALUS TABLES

ISTATISTrCs-Chrso

ICELLS-COUNT EXPECTED SRESID

/COUNT ROUND CEt.L.

INETHOD-EXACT TINER (5).

\section{Crosstabs}

\begin{tabular}{|c|c|c|c|c|c|c|}
\hline & \multicolumn{6}{|c|}{ Cases } \\
\hline & \multicolumn{2}{|c|}{ Valid } & \multicolumn{2}{|c|}{ Missing } & \multicolumn{2}{|c|}{ Total } \\
\hline & $N$ & Percent & $\mathrm{N}$ & Percent & $\mathrm{N}$ & Petcent \\
\hline $\begin{array}{l}\text { DELTA NORTH }=1: \\
\text { DELTA CENTRA }=2 \text {, } \\
\text { DELTA SOUTH }=3=\text { YES } \\
\text { s.NO }=2 \text { :INVALID }=3\end{array}$ & 348 & $100.0 \%$ & 0 & $.0 \%$ & 348 & $100.0 \%$ \\
\hline
\end{tabular}

DELTA NORTH $=1$; DELTA CENTRAL $=2$; DELTA SOUTH $=3 *$ YES $=1 ;$ NO $=2$.INVALID $=$;

\begin{tabular}{|c|c|c|c|c|c|c|}
\hline & & & \multicolumn{3}{|c|}{ YES $=1, N O=2$, INVALID $=3$} & \multirow[b]{2}{*}{ Total } \\
\hline & & & 1 & 2 & 3 & \\
\hline \multirow{9}{*}{$\begin{array}{l}\text { DELTA NORTH }=1 ; \\
\text { DELTA CENTRAL }=2 \text {; } \\
\text { DELTA SOUTH }=3\end{array}$} & 1 & Count & 44 & 70 & 2 & 116 \\
\hline & & Expected Count & 44.3 & 69.7 & 20 & 116.0 \\
\hline & & Std. Residual & 0 & 0 & 0 & \\
\hline & 2 & Count & 44 & 70 & 2 & 116 \\
\hline & & Expected Count & 44.3 & 69.7 & 20 & 116.0 \\
\hline & & Std. Residual & 0 & 0 & 0 & \\
\hline & 3 & Count & 45 & 69 & 2 & 116 \\
\hline & & Expected Count & 44.3 & 69.7 & 2.0 & 1160 \\
\hline & & Std. Residual & 1 & 0 & 0 & \\
\hline \multirow[t]{2}{*}{ Total } & & Count & 133 & 209 & 6 & 348 \\
\hline & & Expected Count & 1330 & 200.0 & 60 & 348.0 \\
\hline
\end{tabular}

\begin{tabular}{|c|c|c|c|c|c|c|}
\hline & Yake & iff & Asymp Sig & $\begin{array}{c}\text { Exact sig } 2 \\
\text { sided }\end{array}$ & $\begin{array}{l}\text { Exact Sig (1. } \\
\text { sibed }\end{array}$ & $\begin{array}{c}\text { Peant } \\
\text { Probabity }\end{array}$ \\
\hline Pearson Chi-Square & 025. & 4 & 1.000 & 1.000 &  & \\
\hline Laveihood Ratio & 025 & 4 & 1000 & 1.000 & & \\
\hline Fsher's Exad Test & 257 & & & 1.000 & & \\
\hline $\begin{array}{l}\text { Linear-by Linew } \\
\text { Association }\end{array}$ & .016 & s & 899 & 949 & 475 & 050 \\
\hline
\end{tabular}

a. 3 cells (93. 3x) have expected court iess than 5 . The minimum expected count as 200 .

b. The standardized statsicic is - 127 . 
